\title{
Effect of protease inhibitors on thermal gelation of squid (Illex argentinus) mantle paste
}

\author{
María E. Paredi a, b*, Emilio A. Manca ${ }^{\mathrm{c}}$, and Marcos, Crupkin ${ }^{\mathrm{a}}$ \\ ${ }^{\text {a }}$ Facultad de Ciencias Agrarias Universidad Nacional de Mar del Plata. Ruta 226 km 73,5 Balcarce, Argentina \\ ${ }^{\mathrm{b}}$ Research of Scientific Research Commission of Buenos Aires Province (CIC) \\ ${ }^{\mathrm{b}}$ National Institute of Research and Development Fishery (INIDEP) Victoria Ocampo s/n Mar del Plata. \\ Argentina \\ * Corresponding author \\ meparedi@mdp.edu.ar \\ TEL/FAX: +54-2266-430456
}

Received: 24 July 2013; Published online: 18 April 2014

\begin{abstract}
The characteristics of the thermal gelation of squid mantle paste and the effect of protease inhibitors on them were investigated. Pastes in the absence and presence the protease inhibitors, ethylendiaminetetracetic acid (EDTA) and phenylmethylsulfonyl fluoride (PMSF), were formulated. Pastes were made by the respective one or two step thermal treatments: direct heating at $85^{\circ} \mathrm{C}$ for 20 min and preincubation at 27 or $40^{\circ} \mathrm{C}$ for 3 or 2 hours, followed by heating at $85^{\circ} \mathrm{C}$ for $20 \mathrm{~min}$. The gel strength, water holding capacity (WHC) and whiteness of gelled pastes were analyzed. The tricloroacetic acid (TCA) soluble peptides in homogenate of the muscle were determined. Gel strength decreased when heating was made in two steps. EDTA and PMSF were effective in avoiding that decrease when preincubation was made at $40^{\circ} \mathrm{C}$. Maximum gel strength was observed for the gels in presence of EDTA, giving values of 255 and $219 \mathrm{~g} \mathrm{x} \mathrm{cm}$ for the samples made by direct heating and pre-incubated at $40^{\circ} \mathrm{C}$ respectively. TCA soluble peptides increased between 20 and $60^{\circ} \mathrm{C}$, with maximum values reached at 30 and $60^{\circ} \mathrm{C}$. No significant differences $(\mathrm{p}>0.05)$ were observed in gel whiteness, neither with the thermal treatment nor with the inhibitors. The WHC was higher $(\mathrm{p}<0.05)$ in the gelated paste formulated with EDTA. These results show a good gelation capacity of $I$. argentinus pastes and improvements with protease inhibitors.
\end{abstract}

Keywords: Thermal gelation; Protease inhibitors; Muscle; Mantle; Squid.

\section{Introduction}

From a commercial point of view based on magnitude of the catch, and the size and meat quality of the specimens, the Ommastrephidae family comprises the most important squid species. The squid (Illex argentinus) is the most significant species in the South West Atlantic Ocean (Hatanaka, 1988; Brunetti, Ivanovic, \& Elena, 1998). About 255,000 tons were caught during 2008-2009 (Redes, Redes \& Sea Food, 2012):
Squids offer some advantages over other seafood, such as high post-processing yield, low lipid content, mild flavor and light color, as well as the functional properties of their proteins (Gomez-Guillen, Martinez-Alvarez, \& Montero, 2003). The characteristics of their proteins make them suitable for use in the manufacture of analogues and other gelled products. However, some cephalopod species have a poor gelforming capacity due to the high proteolytic activity that affects one of the major myofibril- 
lar proteins (Ayensa, An, Gomez-Guillen, Montero, \& Borderias, 1999). In other hand, an increment in gel strength after pre-incubation of the paste or surimi at temperatures between 5 and $40^{\circ} \mathrm{C}$ for a specific time is denomined setting (suwari) (Lanier, 2000). This improvement in the gel textural properties is attributed to endogenous trasglutaminases (TGase) which catalyze the cross-linking reaction of muscle proteins, especially myosin (Kishi, Nozawa, \& Seki, 1991) Whilst information exist on the physicochemical and functional properties of myofibrillar proteins of mantle and fin from Illex argentinus (Paredi \& Crupkin, 1997; Paredi, Roldan, \& Crupkin, 2006; Mignino, Crupkin, \& Paredi, 2008, 2011), knowledge on the heat-induced gelation of mantle proteins and muscle paste from this species of squid is scarce. It is very important for the seafood industry to know the gelling characteristics of the paste obtained from Illex argentinus mantle in order to improve the technological process of manufacture of analogs products. Furthermore, knowledge on the use of heat-induced gelation of mantle proteins from Illex argentinus for the manufacture of re-structured products is scarce (Paredi, Davidovich, \& Crupkin, 1999; Paredi \& Manca, 2006). In addition, there is no information about the effect of protease inhibitors on the gelation characteristics of the mantle paste of Illex argentinus. Therefore, the objective of this work was to investigate the characteristics of heat-induced gelation of squid mantle paste and to analyze the effect of protease inhibitors on them.

\section{Materials and Methods}

Specimens of female squid Illex argentinus (de Castellanos) (dorsal mantle length $210 \mathrm{~mm}$ and total weight range $200-250 \mathrm{~g}$ ) were caught on the Patagonian shelf, at latitude $45-52^{\circ} \mathrm{S}$ in the Southwestern Atlantic Ocean, by commercial vessels equipped with jigging machines. Twelve samples of 10 specimens each were packed in polyethylene bags, fast frozen on board in blocks at $-30^{\circ} \mathrm{C}$ and stored at $-30^{\circ} \mathrm{C}$ until analysis. Frozen samples were partially thawed at time zero (20 days after the catch) and the specimens were gutted and skinned. Some mantles were im- mediately used and others were vacuum-packed in polyethylene bags in lots of 3 mantles, frozen at $-30^{\circ} \mathrm{C}$ in horizontal plates, and stored at the same temperature until analysis. Only specimens at stage 5 (mature) were analyzed. The sexual maturation stage of the specimens was determined by macroscopic observation of the gonads according to Brunetti (1990).

\subsection{Preparation of gels}

Skinned mantles were cut into small pieces with a chopper $(3 \mathrm{~mm})$ and then homogenized for 5 minutes in a domestic food processor (ATMA, Buenos Aires, Argentine), with the addition of $3 \% \mathrm{NaCl}$. Assays in which this paste was formulated, with the addition of $2 \mathrm{mM}$ of ethylendiaminetetracetic acid (EDTA) or $1 \mathrm{mM}$ of meat phenylmethylsulfonyl fluoride (PMSF), were also made. EDTA has been described as an inhibitor of metal proteinases due to chelating power (Mignino, Crupkin, \& Paredi, 2013). PMSF is a characteristic inhibitor of serin-proteases (Mignino et al., 2013). Paste temperature was maintained below $5^{\circ} \mathrm{C}$. The paste resulting from homogenization (78-80\% moisture and 6.3-6.4 $\mathrm{pH})$ was sieved to remove the connective tissue and packed into plastic tubes $(3 \mathrm{~cm} \mathrm{x} 10 \mathrm{~cm})$ for the thermal treatment. This was performed in one or two steps. In the first case, there was direct immersion in a waterbath at $85^{\circ} \mathrm{C}$ for 20 min (in order to reach an internal temperature of $80^{\circ} \mathrm{C}$ ). In the second case, the paste was a heated at $27^{\circ} \mathrm{C}$ for three hours or at $40^{\circ} \mathrm{C}$ for two hours, with subsequent heating at $85^{\circ} \mathrm{C}$ for 20 min. After thermal treatment the tubes were chilled immediately in ice-water for 2 hours and then stored at $4^{\circ} \mathrm{C}$ for 12 hours. Cylindrical samples $(3 \mathrm{~cm}$ high) were removed from the tubes to perform 4 assays for each condition. All determinations in the gelled paste were made in quadruplicate.

\section{$2.2 \quad$ Textural analysis}

\section{Gel strength}

Chilled gels were kept at room temperature $\left(20^{\circ} \mathrm{C}\right)$ for 2 hours and then four cylindrical 
samples $(2.7 \mathrm{~cm} \times 2.5 \mathrm{~cm})$ were removed from the tubes. Breaking strength and deformation were measured using an Instron Model 1442 (INSTRON Corporation, USA), equipped with a cylindrical plunger (5mm diameter), at 20 $\mathrm{mm} / \mathrm{min}$ deformation rate. Gel strength was calculated by multiplying breaking strength (g) by deformation (cm) as described by Lanier (1992).

\subsection{Color determination}

Color of chilled gels was determined using a Minolta CR 300 (Osaka, Japan) colorimeter, according to the CIE scale $\left(\mathrm{L}^{*}, \mathrm{a}^{*}, \mathrm{~b}^{*}\right)$, and whiteness was calculated as described by Lanier (1992).

\subsection{Water holding capacity (WHC)}

WHC was determined in a gel portion of $4 \mathrm{~g}$ by centrifugation at low speed as described by Pietrasik and Li-Chan, 2002 and defined as expressible moisture (EM \%). The expressible moisture was calculated as the percentage of fluid exudates, after centrifugation, with respect to $100 \mathrm{~g}$ of sample.

\subsection{TCA soluble peptides}

TCA soluble peptides were determined according to method described by Toyohara, Sakata, Yamashita, Kinoshita, and Shimizu (1990). One $\mathrm{mL}$ aliquots of the homogenized muscle in $20 \mathrm{mM}$ phosphate buffer, containing $0.6 \mathrm{M} \mathrm{KCl}$, was added to $1 \mathrm{~mL}$ of $20 \% \mathrm{TCA}$, at different times and temperatures of incubation, to precipitate proteins. Absorbance at 280nm was measured in the supernatant, after centrifugation at $6500 \mathrm{x} \mathrm{g}$ for 15 min. (Pagano, Paredi, \& Crupkin, 2001).

\subsection{Scanning Electron Microscopy (SEM)}

The samples were prepared according to the procedure described by Paredi et al. (1999). The samples were fixed in $2 \%$ glutaraldehyde in a $0.2 \mathrm{M}$ phosphate buffer ( $\mathrm{pH} 7.2$ ) and dehydrated in serially increasing concentrations of acetone (from 40-100\%). Then the fixed samples were dried in a critical point dryer and mounted on brass studs. The dried samples were coated with a thin layer of gold in a JEOL JEF. 4x vacuum evaporator and observed by SEM (EVO 40, Cambridge, Enyemol, 2003) with a lower electron detector (LED) at an accelerating voltage of $7 \mathrm{KV}$.

\section{Statistical analysis}

Data was analyzed, by analysis of variance and Duncan's multiple-range test for differences among means, using the statistical analysis package Statistica/MAC (Statistica, Mac, 1994).

\section{Results and discussion}

Figure 1 shows the values of gel strength corresponding to squid mantle paste gels obtained with different thermal treatments in the absence and presence of protease inhibitors. As it can be seen in the control samples (without inhibitor), gel strength was significantly higher $(\mathrm{p}<0.05)$ in the paste gelled by direct heating.

The paste formulated in the presence of inhibitors showed gel strength values that were higher than those of their corresponding controls. Independent of the thermal treatment used, the gel strength values of the samples containing EDTA were significantly $(\mathrm{p}<0.05)$ higher than those corresponding to samples without inhibitor. In presence or absence of inhibitors, the lower values of gel strength were obtained with the paste pre-incubated at $27^{\circ} \mathrm{C}$. Similar results were obtained in presence of EDTA or PMSF.

It is widely known that the gelation properties of surimi (concentrate of myofibrillar proteins) depend on the species used. Only some of them have the capacity to form translucent and elastic gels at temperatures around $40^{\circ} \mathrm{C}$, when these proteins are mixed with salt (setting). For that reason, pre-incubation contributes to an improvement in the characteristics of the gels formed and this process has been related to the presence of endogenous transglutaminase (Lanier, 2000; Kimura et al., 1991). Previous work suggested the presence of transglutaminase in squid (I. argentinus) mantle (Paredi \& 


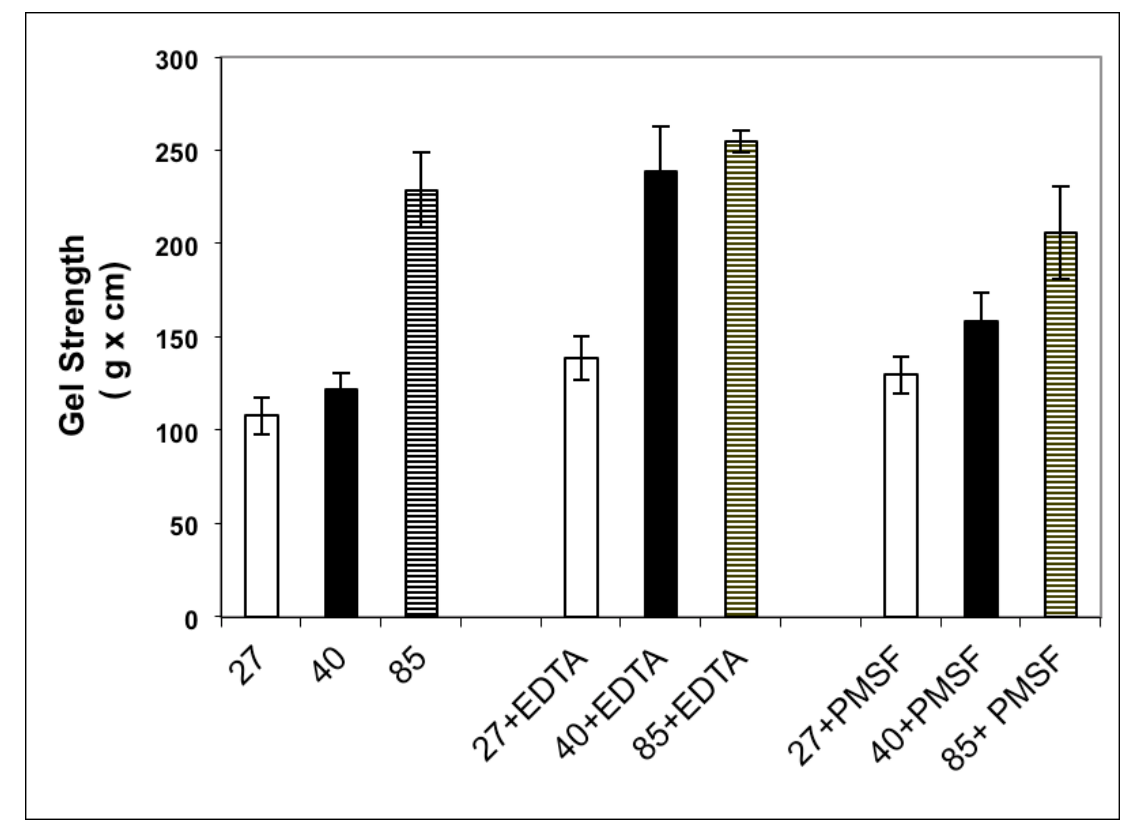

Figure 1: Gel strength of squid mantle paste at different thermal treatments $\left(27,40,85^{\circ} \mathrm{C}\right)$, in absence or in presence of proteases inhibitors (EDTA ,PMSF). The results are expressed as mean \pm SD $(n=10)$.

Crupkin, 2006). A similar presence of transglutaminase was described in marine invertebrates (Nozawa, Mamegoshi, \& Seki, 1997).

Studies on cephalopods reported a decrease in gel strength due to the presence of proteolytic activity that degrades the myosin heavy chain (Nagashima, Ebina, Nagai, Tanaka, \& Taguchi, 1992; Gomez-Guillen, Hurtado, \& Montero, 2002). On the other hand, there are reports that proteases in some squid species show a peak of activity at temperatures between 30 and $40^{\circ} \mathrm{C}$ (Ebina, Nagashima, Ishizaki, \& Taguchi, 1995; Gomez-Guillen et al., 2002).

TCA soluble peptides increased between 20 and $60^{\circ} \mathrm{C}$, and reached a maximum at 40 and $60^{\circ} \mathrm{C}$ (Figure 2). These results indicate the presence of protease activity and provide evidence of autolysis of myofibrillar proteins. Previous studies demonstrated autolysis in homogenates of squid muscle (Illex argentinus) in a similar range of temperatures (Paredi et al., 2006). Similar autolytic activity was described within other cephalopod muscle (Hurtado, Borderias, Montero, \& An, 1999; Gomez-Guillen et al.,
2002). The lower gel strength observed in this work, with pre-incubated samples, can be related to proteolytic activity. The results obtained indicate that the presence of EDTA as well as PMSF efficiently prevent myosin degradation and the fall in gel strength, with EDTA being more efficient. This suggests that at least two kinds of proteases (serine/metallo-proteases) could be acting at the pre-incubation temperatures tested. The peak of proteolytic activity around $40^{\circ} \mathrm{C}$ has been attributed to the specific activity of neutral serine proteases in other cephalopod species (Ebina et al., 1995; Ayensa et al., 1999). Both serin and metallo proteases were recently reported in stored isolated squid actomyosin (Mignino et al., 2013). The presence of proteolytic activity would not allow the manifestation of the setting capacity in the mantle paste.

Figure 3 shows the ultrastructure of gels from squid mantle paste obtained by direct heating at $85^{\circ} \mathrm{C}$ (one step), in the absence and presence of EDTA. As can be seen in Figure 3A the paste without EDTA show more globular 
$64 \mid$ Paredi et al.

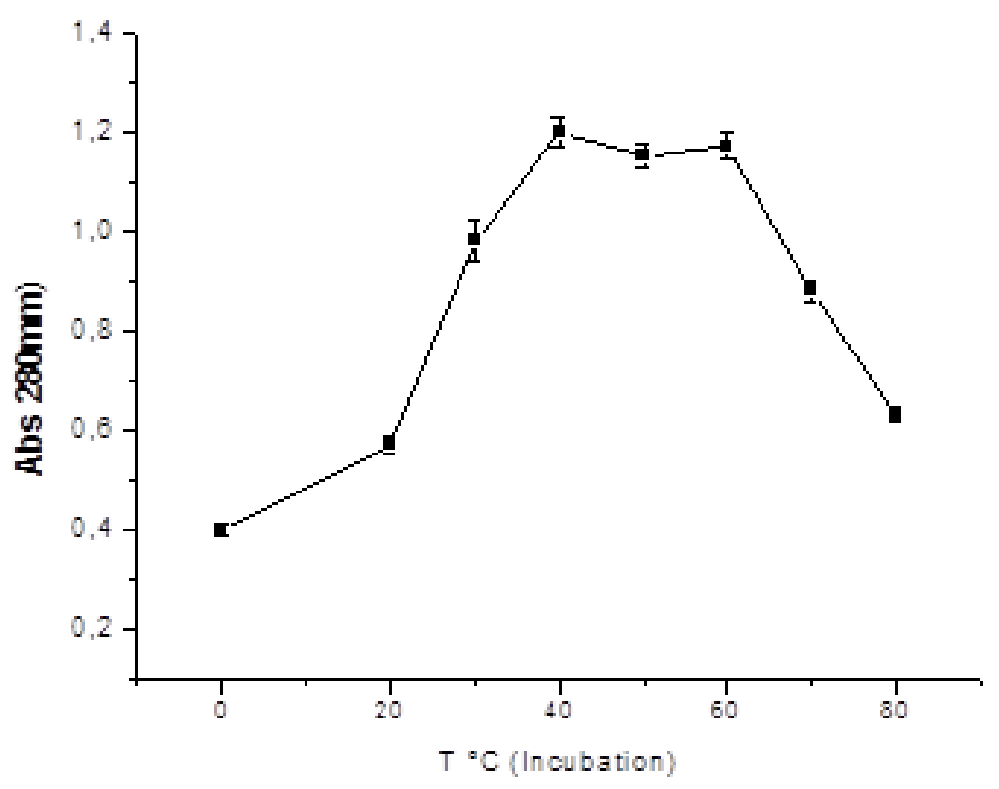

Figure 2: TCA soluble peptides of homogenate muscle, incubated without inhibitor. Each point represent the mean $\pm \mathrm{SD}(\mathrm{n}=6)$.

structures, with small spaces of water retention. However, the ultrastructure of gelled paste with EDTA shows more and uniform spaces for water retention and a better tridimensional structure (Fig. 3B) .The ultrastructure of gelled paste with EDTA is shown at higher magnification in Figure $3 \mathrm{C}$. The presence of EDTA results in higher water retention values. The ultrastructure for gelled pastes, with and without PMSF, show no significant difference (data not shown).

Figure 4 shows the results of expressible moisture (EM) of the gels obtained from squid mantle paste at the different treatments. The waterholding capacity in those gels without incubation was higher than those with incubation. The lowest water-holding capacity was observed in the gels whose paste was incubated at $27^{\circ} \mathrm{C}$ in the presence or absence of inhibitors. EDTA produced a significant decrease $(\mathrm{p}<0.05)$ in the EM of the pre-incubated samples and a nonsignificant decrease in those corresponding to direct heating. Expressible moisture or water- binding capacity are widely used texture indicators (Wasson, Reppond, Babbitt, \& French, 1993). In general, an inverse correlation between expressible moisture and gel strength has been extensively mentioned. On the other hand, different authors described a positive correlation between the loss of water-binding capacity and the proteolytic degradation of myofibrillar proteins in gels obtained from muscle of different fish species (Cheng, Hamann, \& Webb, 1979; ChangLee, Lampila, \& Crawford, 1990; Wasson et al., 1993). A similar behavior occurs in the gels obtained from squid mantle paste, where the highest gel strength has a strong correlation with the lowest expressible moisture, in that paste formulated in the presence of protease inhibitors, especially with EDTA.

Figure 5 shows the results of whiteness (WI) for the gels obtained with the different treatments. No significant differences ( $p>0.05$ ) were observed in this parameter neither by thermal treatment nor with the addition of inhibitors. The values of 


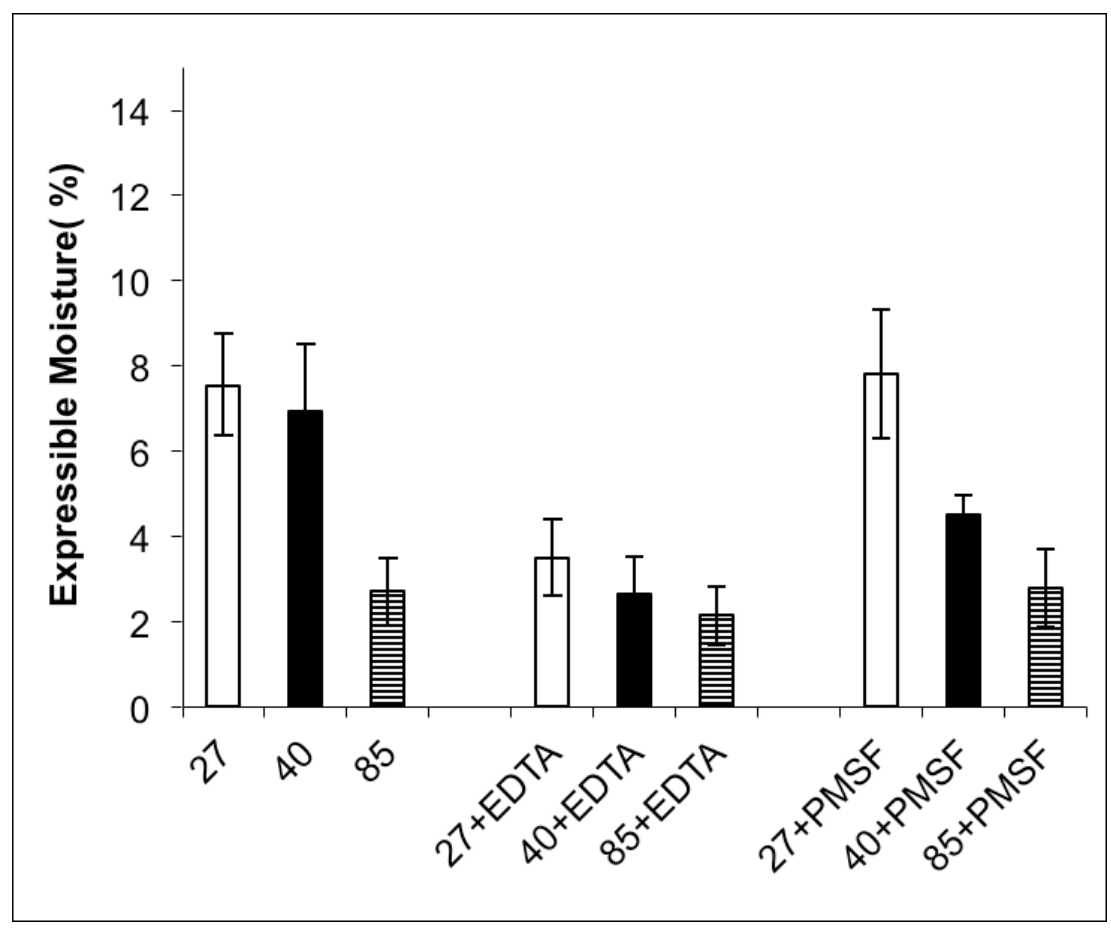

Figure 4: Expressible moisture of squid mantle paste at different treatments, in presence or absence of proteases inhibitors. The results are expressed as mean $\pm \mathrm{SD}(\mathrm{n}=10)$. Other details are shown in Fig. 1

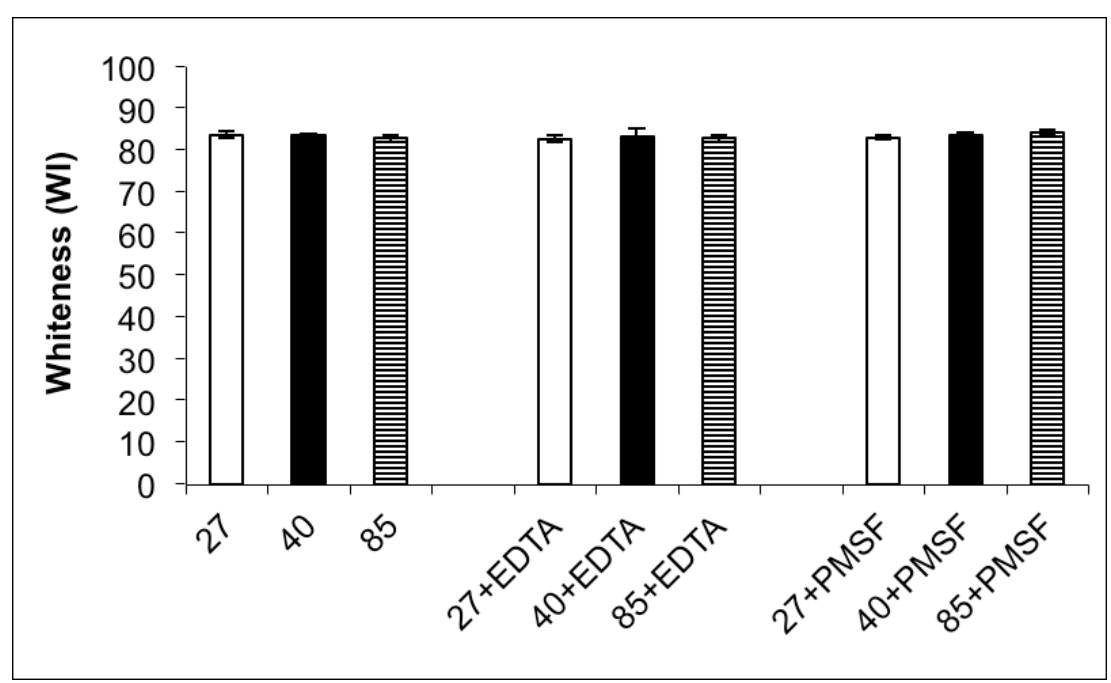

Figure 5: Whiteness of squid mantle paste at different treatments, in presence or absence of proteases inhibitors. The results are expressed as mean $\pm \mathrm{SD}(\mathrm{n}=10)$. Other details are shown in Fig. 1 


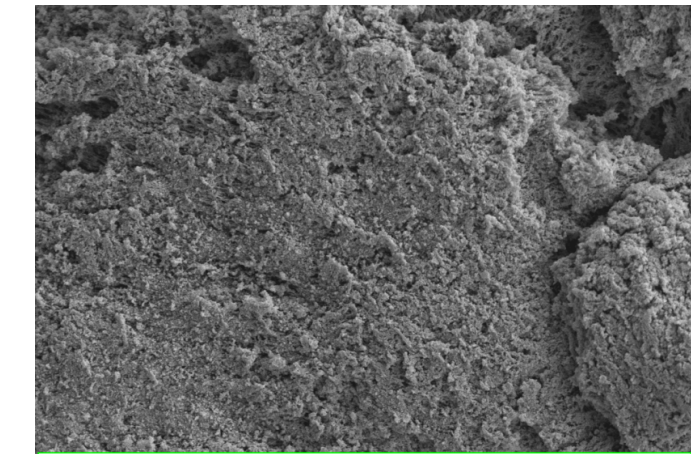

A

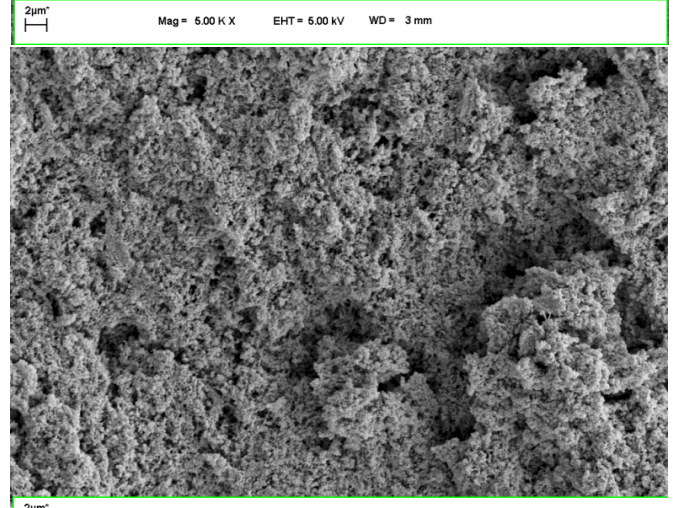

B

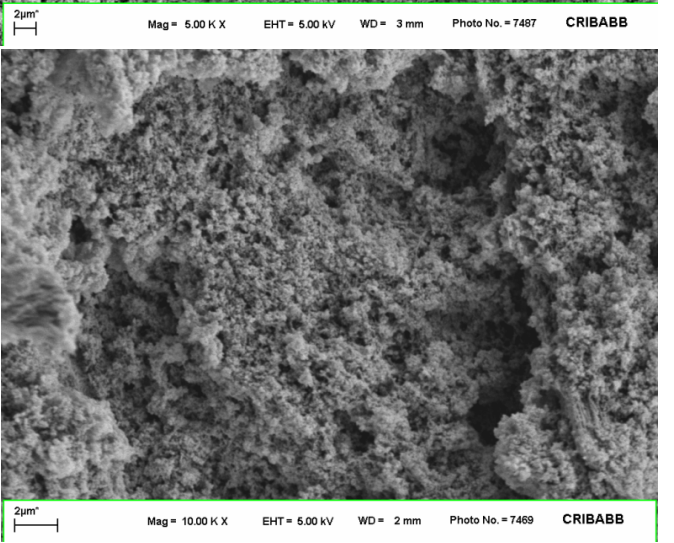

C $\stackrel{2 u m}{\stackrel{2}{\longmapsto}}$

Mag= $10.00 \mathrm{KX}$ EHT $-5.00 \mathrm{kV}$ WD $=2 \mathrm{~mm}$ Photo No. -7469 CRIBABB

Figure 3: Scanning electron micrographs of gels from squid mantle paste, with direct heating $\left(85^{\circ} \mathrm{C}\right)$ : (A) control 5000x; (B) paste with EDTA $5000 \mathrm{x}$; and $(\mathrm{C})$ paste with EDTA $10.000 \mathrm{x}$
WI are considered as optimum for these gelated products (Lanier, 1992).

\section{Conclusions}

In this paper a good gelation capacity of paste from squid mantle is reported. Gel strength and water-holding capacity can be improved with the addition of protease inhibitors. According to the inhibitors used the presence of metallo- or serine-proteases in the $I$. argentinus paste are suggested, with a higher preponderance of the first one. The inhibitors were effective when gelation was performed in 2 steps. The presence of EDTA improved the gel strength and ultrastructure of the gels. The characteristics of their proteins make them suitable to be used in the manufacture of analogues and other gelled products.

\section{Acknowledgements}

We thank the Comisión de Investigaciones Científicas de la Pcia. de Bs. As. (CIC) and the Universidad Nacional de Mar del Plata. We thank Dr Brunetti for her contribution and work on the gonadal stage determination.

\section{References}

Ayensa, M. G., An, H., Gomez-Guillen, M. C., Montero, P., \& Borderias, A. J. (1999, October). Partial protease activity characterization of squid (todaropsis eblanae) mantle. Food Science and Technology International, 5(5), 391-396. doi:10.1177/ 108201329900500504

Brunetti, N. E. (1990). Escala para la identificación de estadíos de madurez sexual del calamar Illex argentinus.(an escale for identification of stages of sexual maturity in the argentine squid (Illex argentinus)). Frente Marítimo, 7, 45-51.

Brunetti, N. E., Ivanovic, M. L., \& Elena, B. (1998). Calamares omastréfidos (Cephalopoda, Ommastrephidae). In: E.E. Boschi (ed.). El Mar Argentino y sus recursos pesqueros. Tomo 2. Los moluscos de interés pesquero. Cultivos y estrategias reproductivas de bivalvos 
y equinoideos. Mar del Plata: Instituto Nacional de Investigación y Desarrollo Pesquero, 37-68.

Chang-Lee, M. V., Lampila, L. E., \& Crawford, D. L. (1990). Yield and composition of surimi from pacific whiting (MerlucciusProductus) and the effect of various protein additives on gel strength. Journal of Food Science, 55(1), 83-86. doi:10.1111/j.13652621.1990.tb06022.x

Cheng, C. S., Hamann, D. D., \& Webb, N. B. (1979). Effect of thermal-processing on minced fish gel texture. Journal of Food Science, 44(4), 1080-1086. doi:10.1111/j. 1365-2621.1979.tb03452.x

Ebina, H., Nagashima, Y., Ishizaki, S., \& Taguchi, T. (1995). Myosin heavy chaindegrading proteinase from spear squid muscle. Food Research International, 28(1), 31-36. doi:10.1016/0963-9969(95)93328-R

Gomez-Guillen, M. C., Hurtado, J. L., \& Montero, P. (2002). Autolysis and protease inhibition effects on dynamic viscoelastic properties during thermal gelation of squid muscle. Journal of Food Science, 67(7), 24912496. doi:10 . $1111 /$ j . 1365 - 2621 . 2002 . tb08764.x

Gomez-Guillen, M. C., Martinez-Alvarez, O., \& Montero, P. (2003). Functional and thermal gelation properties of squid mantle proteins affected by chilled and frozen storage. Journal of Food Science, 68(6), 19621967. doi:10 . $1111 /$ j . 1365 - 2621 . 2003. tb07002.x

Hatanaka, H. (1988). Feeding migration of shortfinned squid Illex argentinus in the waters off argentina. Nippon Suisan Gakkaishi, 54 (8), 1343-1349.

Hurtado, J. L., Borderias, J., Montero, P., \& An, H. J. (1999). Characterization of proteolytic activity in octopus (octopus vulgaris) arm muscle. Journal of Food Biochemistry, 23(4), 469-483. doi:10.1111/j. 1745-4514.1999.tb00031.x

Kimura, I., Sugimoto, M., Toyoda, K., Seki, N., Arai, K., \& Fujita, T. (1991). A study on the cross-linking reaction of myosin in kamaboko 'suwari' gels. Nippon Suisan Gakkaishi, 57(7), 1389-1396.
Kishi, H., Nozawa, H., \& Seki, N. (1991). Reactivity of muscle transglutaminase on carp myofibrils and myosin B. Nippon Suisan Gakkaishi, 57(6), 1203-1210.

Lanier, T. C. (1992). Measurement of surimi composition and functional properties. Surimi Technology, 123-163.

Lanier, T. C. (2000). Surimi gelation chemistry. In: J.W. Park (Ed). Surimi and surimi seafood, 237-266. New York, USA, Marcel Dekker.

Mignino, L. A., Crupkin, M., \& Paredi, M. E. (2008). Surface hydrophobicity and functional properties of myofibrillar proteins of mantle from frozen-stored squid (Illex argentinus) caught either jigging machine or trawling. LWT-Food Science and Technology, 41(4), 678-685. doi:10.1016/j. lwt . 2007.05.006

Mignino, L. A., Crupkin, M., \& Paredi, M. E. (2011). Influence of the capture method on the physicochemical and functional properties of myofibrillar proteins of fin from frozen, stored squid (Illex argentinus). Journal of Shellfish Research, 30(3), 915921. doi:10.2983/035.030.0333

Mignino, L. A., Crupkin, M., \& Paredi, M. E. (2013). Proteolytic activity in actomyosinfrom mantle and fin of squid (Illex argentinus) stored at $2-4^{\circ} \mathrm{c}$. influence on the physicochemical and functional properties of the protein. Journal of Food Research, $2(2)$

Nagashima, Y., Ebina, H., Nagai, T., Tanaka, M., \& Taguchi, T. (1992). Proteolysis affects thermal gelation of squid mantle muscle. Journal of Food Science, 57(4), 916917. doi:10 . 1111 / j. 1365 - 2621 . 1992 . tb14322.x

Nozawa, H., Mamegoshi, S., \& Seki, N. (1997). Partial purification and characterization of six transglutaminases from ordinary muscles of various fishes and marine invertebrates. Comparative Biochemistry and Physiology B-biochemistry \& Molecular Biology, 118(2), 313-317. doi:10.1016/S03050491(97)00062-X

Pagano, M. R., Paredi, M. E., \& Crupkin, M. (2001). Autolysis of proteins from prespawned hake (Merluccius hubbsi Marini) 
during in vitro storage of myofibrils at 20 and $37^{\circ} \mathrm{C}$. Journal of Food Biochemistry, $25(6), 569-585$.

Paredi, M. E. \& Crupkin, M. (1997, May). Biochemical properties of actomyosin from frozen stored mantles of squid (Illex argentinus) at different sexual maturation stages. Journal of Agricultural and Food Chemistry, 45(5), 1629-1632. doi:10.1021/ jf960776c

Paredi, M. E. \& Crupkin, M. (2006). Autólisis de proteínas y actividad de transglutaminasa en manto de calamar (Illex argentinus). Paper presented at VI Jornadas Nacionales de Ciencias del Mar. Centro Nacional Patagónico, Puerto Madryn, Argentina. 37 December 2006. Puerto Madryn: CONICET.

Paredi, M. E., Davidovich, L. A., \& Crupkin, M. (1999). Thermally induced gelation of squid (Illex argentinus) actomyosin. influence of sexual maturation stage. Journal of Agricultural and Food Chemistry, 47(9), 3592-3595. doi:10.1021/jf9812681

Paredi, M. E. \& Manca, E. (2006). Gelación inducida por calor de pasta de manto de calamar Illex argentinus. Paper presented at Congreso Internacional de Ciencia Y Tecnologia de Alimentos, Held at Convention Centre Holiday Inn, Córdoba., 15-16 November 2006. Córdoba: Córdoba Ciencia.

Paredi, M. E., Roldan, H. A., \& Crupkin, M. (2006). Changes in myofibrillar proteins and lipids of squid (Illex argentinus) during frozen storage. Journal of Food Biochemistry, 30(5), 604-621. doi:10.1111/j.17454514.2006.00088.x

Pietrasik, Z. \& Li-Chan, E. C. Y. (2002). Binding and textural properties of beef gels as affected by protein, kappa-carrageenan and microbial transglutaminase addition. Food Research International, 35(1), 91-98. doi:10.1016/S0963-9969(01)00123-5

Redes, Redes \& Sea Food. (2012, May). Revista redes de la indsutria pesquera argentina. 184, 11:26.

Statistica, Mac. (1994). Statistica for Macintosh. Statsoft. Inc. Tulsa. O.K. USA. Retrieved from http://www.statsoft.com/company / about-us/reviews/1994-published-reviews

Toyohara, H., Sakata, T., Yamashita, K., Kinoshita, M., \& Shimizu, Y. (1990). Degradation of oval-filefish meat gel caused by myofibrillar proteinase(s). Journal of Food Science, 55(2), 364-368. doi:10.1111/ j . 1365-2621.1990.tb06764.x

Wasson, D., Reppond, K., Babbitt, J., \& French, J. (1993). Effects of additives of proteolytic and functional properties of arrowtooth flounder surimi. Journal of Aquatic Food Product Technology, 1(3-4), 147-165. 